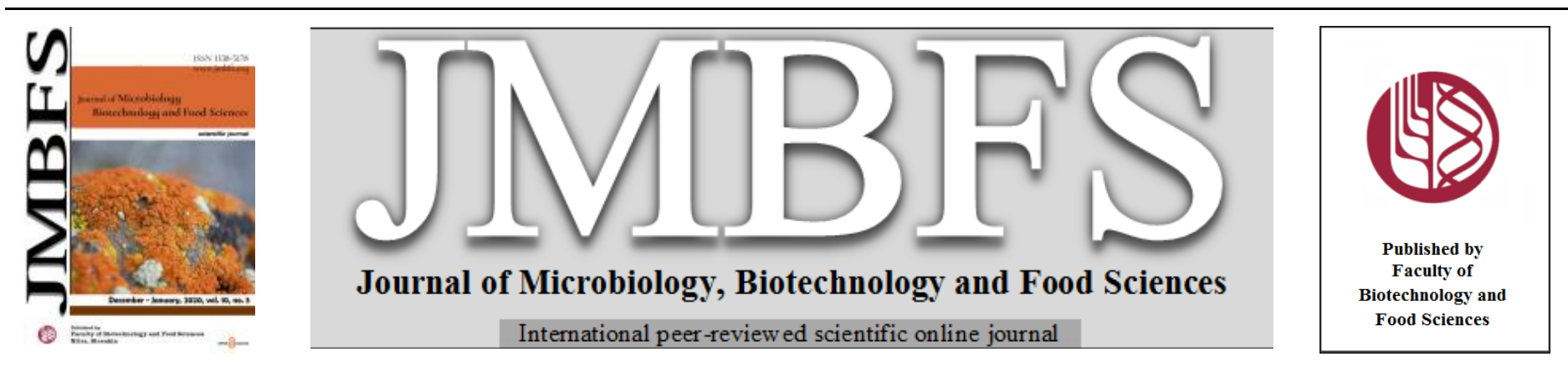

\title{
PRODUCTION AND PURIFICATION OF KILLER TOXIN FROM PROBIOTIC YEASTS AND ITS EFFECT ON FOODBORNE PATHOGENS
}

\author{
Mangala Lakshmi Ragavan ${ }^{1}$ and Nilanjana Das $*^{2}$ \\ Address(es): \\ 1,2, Bioremediation Laboratory, School of Bio Sciences and Technology, VIT (Vellore Institute of Technology), Vellore-632014, Tamil Nadu, India. Tel.: +91 416 \\ 2202478; Fax: +91 4162243092.
}

*Corresponding author: nilanjanamitra@ vit.ac.in

doi: 10.15414/jmbfs.2020.10.3.350-353

\section{ARTICLE INFO}

Received 4. 6. 2020

Revised 4. 7. 2020

Accepted 6. 7. 2020

Published 1. 12. 2020

Regular article

OPEN $\partial_{\text {AcCESS }}$

\begin{abstract}
Probiotic yeast strains viz. Yarrowia lipolytica VIT-MN01, Kluyveromyces lactis VIT-MN02, Lipomyces starkeyi VIT-MN03, Saccharomycopsis fibuligera VIT-MN04 and Brettanomyces custersianus VIT-MN05 were investigated as producer of killer toxin. Among the five yeasts, three strains showed more killer toxin production. The maximum killer activity $(12 \mathrm{aU} / \mathrm{mg})$ against sensitive strain Saccharomyces cerevisiae was obtained at $\mathrm{pH}-3$ with $0.5 \% \mathrm{NaCl}$ at $25^{\circ} \mathrm{C}$ by using response surface methodology. The purified killer toxin K2 and K3 showed the highest killer activity against foodborne pathogens viz. Bacillus cereus, E. coli, Pseudomonas spp., Klebsiella spp. and Candida tropicalis. The purity of the killer toxin was confirmed by HPLC analysis. The molecular mass of killer toxin was $22 \mathrm{kDa}(\mathrm{K} 2), 18 \mathrm{kDa}(\mathrm{K} 3)$ and $14 \mathrm{kDa}(\mathrm{K} 4)$. The results of the present study suggest that killer toxins produced by probiotic yeast strains can be used as an antimicrobial agent to control the microbial contamination in the food industry.
\end{abstract}

Keywords: Antimicrobial activity, foodborne pathogens, killer toxin, probiotic yeasts

\section{INTRODUCTION}

Yeasts are capable of producing antimicrobial compounds (killer toxins) that may inhibit the growth of harmful mold or bacteria (Younis et al., 2017). Killer yeast and their toxins are having environmental, technological and medical importance. It is possible to screen killer yeast toxins as a potentially novel chemotherapy agent. Killer yeasts have been reported in probiotics, which stimulate immune responses, prevent various enteric diseases, diarrhoea and improve host health (Kaur and Tiwari, 2016). The killer toxin production by various genera of yeast species such as Candida, Saccharomyces cerevisiae, Ustilago, Kluyveromyces, Debaromyces, Pichia, Wiliopsis and, Zygosaccharomyces have been reported (Parveen and Begum, 2010). Killer toxins may have potential applications in various industrial sectors such as food, pharmaceutical, agricultural and fermentation due to its antagonism activity against pathogens (Lopes and Sangorrin, 2010; Chi et al., 2010). The killer yeast can be used as starter cultures to prevent contamination of wild yeast in alcoholic fermentation industries viz. distilleries, breweries, wineries (Bajaj et al., 2012). The effect of killer toxin is dependent on its potency and susceptibility of treated cells under selected conditions. Parameters like $\mathrm{pH}$, temperature and $\mathrm{NaCl}$ have an effect on killer toxin production (Golubev, 2013; Belgacem et al., 2012).

In the present study, five probiotic yeast strains viz. $Y$. lipolytica VIT-MN01, $K$ lactis VIT-MN02, L. starkeyi VIT-MN03, S. fibuligera VIT-MN04 and $B$. custersianus VIT-MN05 were investigated for their killer toxin production. The purified killer toxin was tested for antimicrobial activity against foodborne pathogens viz. Bacillus cereus, E. coli, Pseudomonas spp. and Klebsiella spp. and Candida tropicalis. The purity and molecular weight of killer toxin was assessed by HPLC and SDS-PAGE, respectively.

\section{MATERIAL AND METHODS}

\section{Yeasts strains and media}

Probiotic yeasts strains viz. $Y$. lipolytica VIT-MN01, K. lactis VIT-MN02, $L$. starkeyi VIT-MN03, S. fibuligera VIT-MN04 and B. custersianus VIT-MN05 were isolated from different sources and reported as potential probiotics (Ragavan and Das, 2017). These strains were grown in YEPD medium and incubated at $30^{\circ} \mathrm{C}$ for $24-48 \mathrm{~h}$. The pellet was centrifuged at $5000 \mathrm{rpm}$ for $15 \mathrm{~min}$ and washed twice with PBS buffer and stored at $4{ }^{\circ} \mathrm{C}$ for further analysis.

\section{Killer toxin production}

Yeasts strains were inoculated on KTP medium and incubated for $72 \mathrm{~h}$ at $30^{\circ} \mathrm{C}$ for killer toxin production. The culture was centrifuged at $10000 \mathrm{rpm}$ for $15 \mathrm{~min}$ and the cell-free supernatant was collected. Then supernatant filtered through $0.45 \mu \mathrm{m}$ membrane filter and precipitated by centrifugation at $10000 \mathrm{rpm}$ for 20 mins and resuspended in $0.1 \mathrm{M}$ citrate buffer $(\mathrm{pH}-4.2)$. The crude toxin was stored at $4^{\circ} \mathrm{C}$ until use (Parveen and Begum, 2010).

\section{Experimental design}

The effect of temperature (A), $\mathrm{pH}(\mathrm{B})$ and $\mathrm{NaCl}(\mathrm{C})$ on killer toxin production (response) was studied using Box Behnken design (BBD) by response surface methodology (RSM) (Belgacem et al., 2012). The 2D and 3D contour plots were prepared to know the effects of different factors viz. A, B, and $\mathrm{C}$ on killer toxin production. Three levels $(-1,0,+1)$ used in this study were given in Table 1 .

Table 1 Three levels used in this study

\begin{tabular}{llccc}
\hline No. & Parameters & Level -1 & Level 0 & Level +1 \\
\hline 1 & $\mathrm{pH}$ & 2 & 3 & 4 \\
2 & Temperature $\left({ }^{\circ} \mathrm{C}\right)$ & 20 & 25 & 30 \\
3 & $\mathrm{NaCl}(\%)$ & 0 & 0.5 & 1 \\
\hline
\end{tabular}

A quadratic model was performed to calculate the analysis of variance (ANOVA). The experimental designs and regression analysis was done by Design-Expert software (Version 11).

\section{Killer activity assay}

The killer assay medium (KAM medium) was prepared and pre spread with sensitive strain Saccharomyces cerevisiae. The wells of $7 \mathrm{~mm}$ diameter were made in which $50 \mu \mathrm{l}$ of crude toxin was pipetted and incubated for $24 \mathrm{~h}$ at $30^{\circ} \mathrm{C}$. The zone of inhibition was observed, and killer activity was expressed in terms of Arbitrary Units (AU) (Bajaj and Sharma, 2010). 


\section{Purification of a killer toxin}

The crude toxin was precipitated by $30 \%$ ammonium sulphate and incubated for overnight at $4^{\circ} \mathrm{C}$ and protein was harvested by centrifugation at $10000 \mathrm{rpm}$ for 10 min. The residue was dissolved in $50 \mathrm{mM}$ sodium acetate buffer $(\mathrm{pH} 3.8)$ and dialyzed with the same for $4 \mathrm{~h}$ at $4^{\circ} \mathrm{C}$. The solution was applied to preequilibrated diethylaminoethyl (DEAE) Sepharose Fast Flow anion exchange column. The bounded protein (killer toxin) was eluted in acetate buffer with 0.5 $\mathrm{M} \mathrm{NaCl}$ (Buzdar et al., 2011)

\section{Antimicrobial activity of the killer toxin}

The overnight pathogenic cultures of bacteria viz. B. cereus, E. coli, Pseudomonas spp., Klebsiella spp. and yeast, C. tropicalis were swabbed in MHA and YEPD agar plate respectively. Agar well diffusion assay was performed with $50 \mu \mathrm{l}$ of crude toxin and incubated for $24 \mathrm{~h}$ at $30^{\circ} \mathrm{C}$ and the zone of inhibition was observed (Hernandez et al., 2008; Amin et al., 2013).

\section{HPLC analysis}

The purity of killer toxin was analyzed by reverse-phase C-18 column ( $250 \mathrm{x}$ $4.60 \mathrm{~mm}$ ) and UV detector at $280 \mathrm{~nm}$. Acetonitrile and water (80:20) mixture was used as a solvent system at a flow rate of $0.5 \mathrm{ml} / \mathrm{min}$. The killer protein 100 $\mu 1$ was injected on HPLC and chromatogram was obtained over a period of 15 mins (Santos et al., 2009).

\section{SDS analysis}

The molecular mass of killer toxins was determined by SDS-PAGE analysis The killer protein $(20 \mu \mathrm{l})$ was mixed with $5 \mu \mathrm{l}$ sample loading dye $(250 \mathrm{mM}$ Tris $\mathrm{HCl}, 10 \%$ SDS, 30\% (v/v) Glycerol, $10 \mathrm{mM} \mathrm{DTT,} 0.05 \%$ (w/v) bromophenol blue, $\mathrm{pH}$ 6.8) and loaded on $12 \%$ SDS gel. The protein was stained with coomassie blue R-250 (Sigma) and compared with known marker protein (Laemmli, 1970).

\section{RESULTS AND DISCUSSION}

Five probiotic yeasts strains showed killer toxin production against sensitive $S$ cerevisiae (Fig. 1a). The KAM plates showed that K2 and K3 indicate highest killer activity than K4 (Fig. 1b). Among the five strains, three yeasts namely, $K$ lactis VIT-MN02 (K2), L. starkeyi VIT-MN03 (K3) and S. fibuligera VIT-MN04 (K4) exhibited more killer activity (Fig. 1).

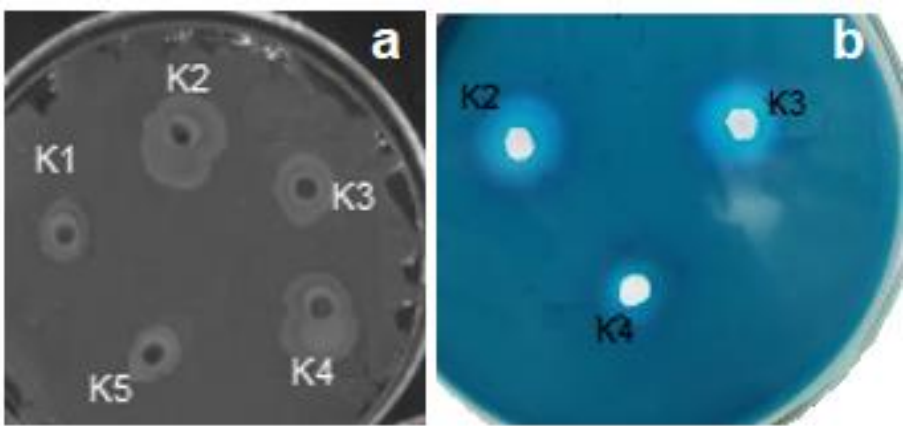

Figure 1 Screening for killer strains against sensitive strain Saccharomyces cerevisiae

(a)Screening for killer toxin production in KTP media and (b) Killer activity against sensitive strain $S$. cerevisiae on KAM media.

(K1-Y. lipolytica VIT-MN01 toxin, K2- K. lactis VIT-MN02 toxin, K3- L. starkeyi VIT-MN03 toxin, K4- $S$. fibuligera VIT-MN04 toxin, K5- B. custersianus VIT-MN05 toxin)

There are reports on killer toxin production, few yeasts strains of Kluyveromyces $s p$. and other species like W. saturnus WC91-2, P. anomala YF07b and $S$ cerevisiae showed similar killer activity (Golubev, 2013; Buzdar et al., 2011; Parveen and Begum, 2010). The effect of temperature (A), $\mathrm{pH}(\mathrm{B})$ and $\mathrm{NaCl}$ concentration $(\mathrm{C})$ on killer toxin production was investigated using RSM. The highest killer activity $(12 \mu \mathrm{g} / \mathrm{ml})$ was observed at $25^{\circ} \mathrm{C}$ with $\mathrm{pH}-3$ and $0.5 \%$ $\mathrm{NaCl}$. The lower $\mathrm{pH}$ and $\mathrm{NaCl}$ increased the killer activity. 2D and 3D plots for the effect of temperature, $\mathrm{pH}$, and $\mathrm{NaCl}$ on killer activity were illustrated in Fig. 2
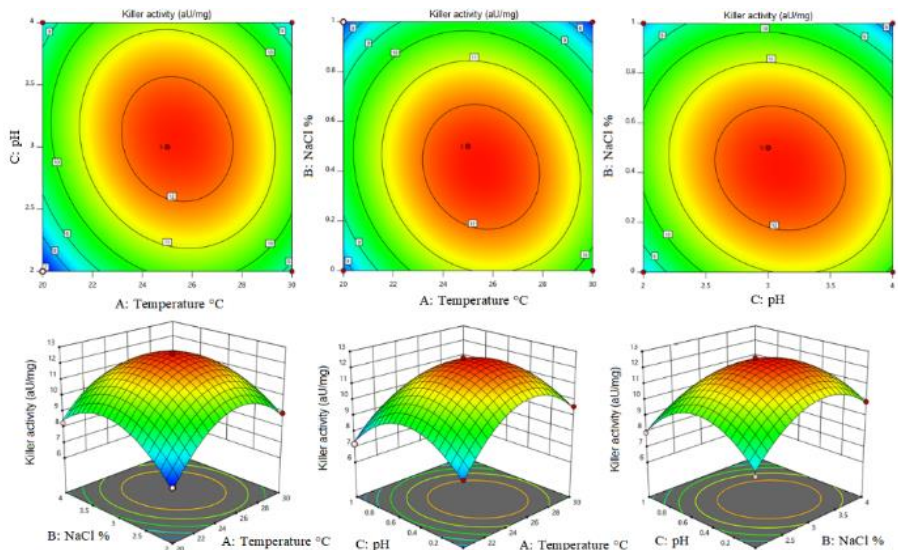

Figure 2 Effects of different parameters on killer toxin production by probiotic yeast

(A) Temperature, (B) $\mathrm{pH},(\mathrm{C}) \mathrm{NaCl}$

Many yeasts strains have been reported for their highest killer activity when the cells were grown at $25^{\circ} \mathrm{C}$. Killer toxin showed maximum activity at $\mathrm{pH}-3$, which revealed that protein has a net positive charge because the isoelectric point of the killer toxin was pH-4.5 (Pfeiffer and Radler, 1928). These results suggest that killer toxin can efficiently attach on the surface of gram-negative bacteria and inhibit their growth. The actual and predicted values for killer toxin production were shown in Fig. 3. ANOVA for the quadratic model was given in Table 2.

Table 2 ANOVA for Quadratic model

\begin{tabular}{|c|c|c|c|c|c|}
\hline Source & Sum of Squares & $\mathrm{df}$ & Mean Square & F-value & p-value \\
\hline Model & 76.11 & 9 & 8.46 & 106.63 & $0.0001 * * *$ \\
\hline A-A & 1.46 & 1 & 1.46 & 18.44 & $0.0036^{*}$ \\
\hline B-B & 0.6874 & 1 & 0.6874 & 8.67 & $0.0216^{*}$ \\
\hline $\mathrm{C}-\mathrm{C}$ & 3.37 & 1 & 3.37 & 42.54 & $0.0003 *$ \\
\hline $\mathrm{AB}$ & 1.08 & 1 & 1.08 & 13.64 & $0.0077 *$ \\
\hline $\mathrm{AC}$ & 1.10 & 1 & 1.10 & 13.90 & $0.0074 *$ \\
\hline $\mathrm{BC}$ & 1.14 & 1 & 1.14 & 14.37 & $0.0068^{*}$ \\
\hline $\mathrm{A}^{2}$ & 25.14 & 1 & 25.14 & 317.03 & $0.0001 * * *$ \\
\hline $\mathrm{B}^{2}$ & 15.89 & 1 & 15.89 & 200.31 & $0.0001 * * *$ \\
\hline $\mathrm{C}^{2}$ & 19.24 & 1 & 19.24 & 242.55 & $0.0001 * * *$ \\
\hline Residual & 0.5551 & 7 & 0.0793 & & \\
\hline Lack of Fit & 0.3661 & 3 & 0.1220 & 2.58 & 0.1909 \\
\hline Pure Error & 0.1891 & 4 & 0.0473 & & \\
\hline Cor Total & 76.66 & 16 & & & \\
\hline Std. Dev. & 0.2816 & & & & \\
\hline Mean & 9.39 & & & & \\
\hline C.V. $\%$ & 3.00 & & & & \\
\hline $\mathrm{R}^{2}$ & 0.9928 & & & & \\
\hline Adjusted $\mathrm{R}^{2}$ & 0.9834 & & & & \\
\hline Predicted $\mathrm{R}^{2}$ & 0.9197 & & & & \\
\hline Adeq Precision & 26.0509 & & & & \\
\hline
\end{tabular}

*** Highly Significant; * Significant.
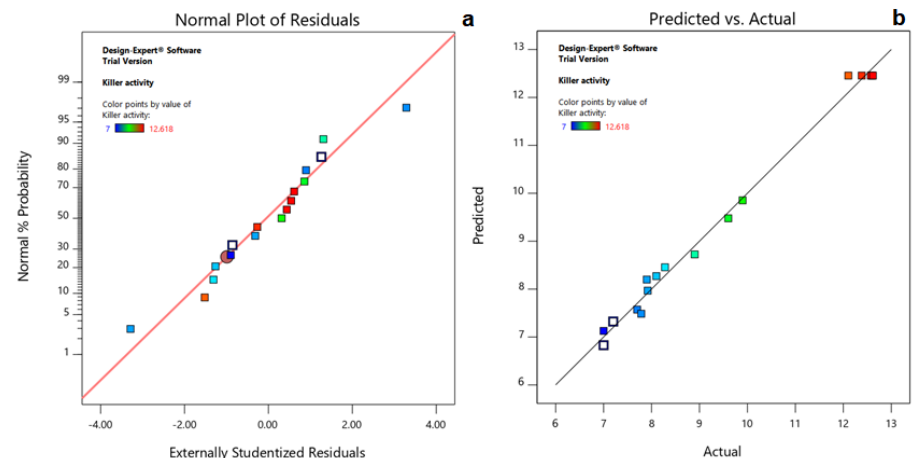

Figure 3 Actual and predicted values for killer toxin production

Antimicrobial activity against B. cereus, E. Coli, Pseudomonas spp., Klebsiella spp. and $C$. tropicalis were observed in $\mathrm{K} 2$ and $\mathrm{K} 3$. In case of $\mathrm{K} 4$, activity was noted against E. Coli, Pseudomonas spp. and C. tropicalis. The killer activity was 
found to be less in K5 against B. cereus (Fig. 4). Protease treated killer toxins served as a control plate for antimicrobial activity against all pathogens either individually (not shown) or as a mixture of all pathogens (Fig. 4f).

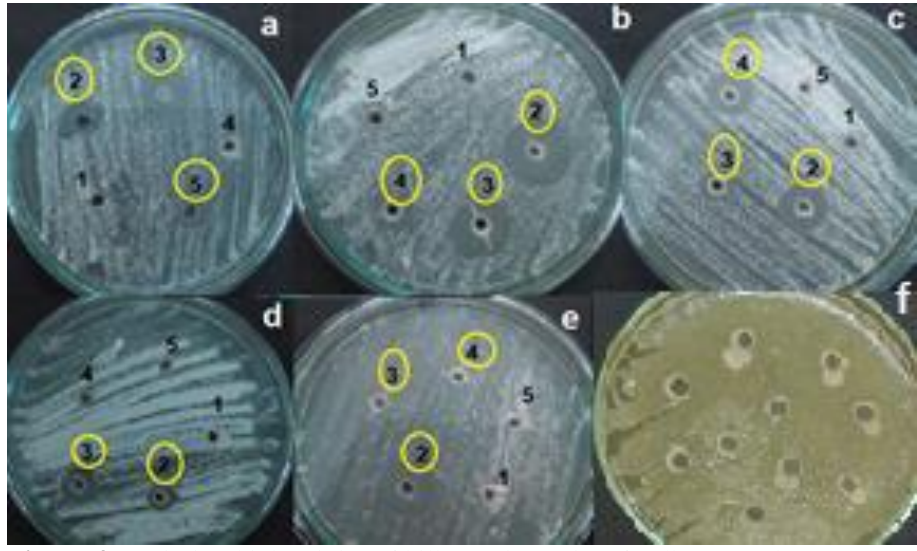

Figure 4. Antimicrobial activity of killer toxin against foodborne pathogens

(a) B. cereus, (b) E. coli, (c) Pseudomonas spp., (d) Klebsiella spp., (e) C. tropicalis, (f) Protease treated killer toxin from five probiotics (Control plate)

Moreover, the purified killer protein showed protease activity, which indicated that the inhibition was occurred only by a killer toxin (data not shown). These results suggest that the killer activity of yeasts can be chosen to control bacteria contamination during fermentation (Meneghin et al., 2010). Probiotic strain Lactobacillus plantarum $2 \mathrm{~S}$ have been reported for broad antimicrobial activity spectrum against gram positive and gram negative bacteria (François $\boldsymbol{e t}$ al., 2013). The quantification of purified killer toxin from probiotic yeasts and their killer activities were given in Table 3 .

Table 3 Purified killer protein from probiotic yeast strains

\begin{tabular}{lll}
\hline Probiotic yeasts & $\begin{array}{l}\text { Total protein } \\
(\mathrm{mg} / 100 \mathrm{ml})\end{array}$ & $\begin{array}{l}\text { Specific activity } \\
\left(10^{4} \mathrm{aU} / \mathrm{mg}\right)\end{array}$ \\
\hline Y. lipolytica VIT-MN01 & $0.88 \pm 0.21$ & $0.3 \pm 0.08$ \\
K. lactis VIT-MN02 & $48 \pm 1.23$ & $12 \pm 0.86$ \\
L. starkeyi VIT-MN03 & $46 \pm 2.32$ & $10 \pm 0.54$ \\
S. fibuligera VIT-MN04 & $32 \pm 1.76$ & $6 \pm 1.76$ \\
B. custersianus VIT-MN05 & $0.56 \pm 0.33$ & $0.1 \pm 0.06$ \\
\hline
\end{tabular}

Average values in $( \pm) \mathrm{SD}$

Few killer toxin producing strains (bacteria and yeasts) have been reported to show killer activity towards specific strains. The results of the present study suggest that the selected probiotic yeasts strain may have a wide range of antimicrobial activity.

HPLC and SDS-PAGE analysis confirmed the purity of killer toxin. The HPLC chromatogram of K2, K3 and K4 showed a single peak at 2.867, 4.031, and 3.698 min, respectively (Fig. 5).

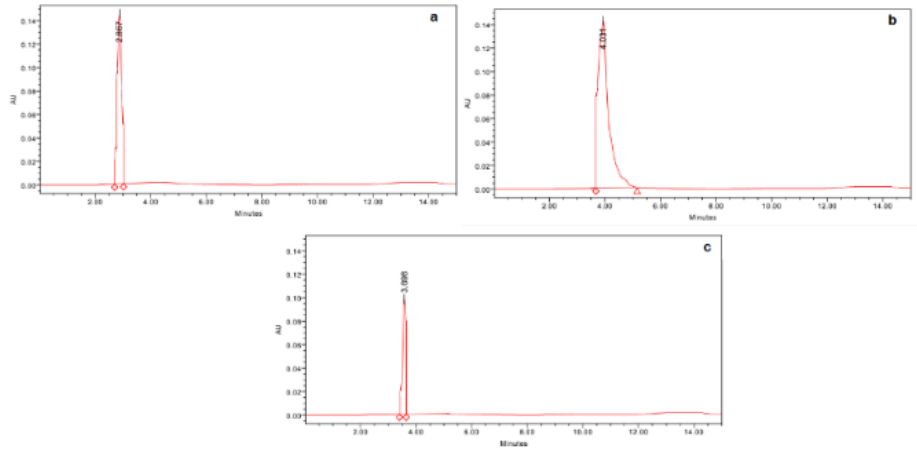

Figure 5 HPLC analysis for a purified killer toxin. (a)K2, (b) K3 and (c) K4

The SDS PAGE showed protein bands at $22 \mathrm{kDa}$, $18 \mathrm{kDa}$, and $14 \mathrm{kDa}$ for $\mathrm{K} 2$, K3, and $\mathrm{K} 4$, respectively (Fig. 6).

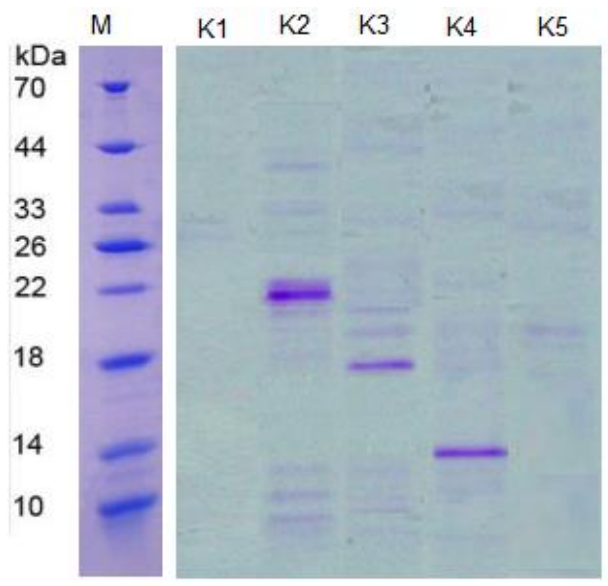

Figure 6 SDS-PAGE of purified killer toxin from probiotic yeasts.

M- Protein marker; K1-Y. lipolytica VIT-MN01 toxin, K2- K. lactis VIT-MN02 toxin, K3- L. starkeyi VIT-MN03 toxin, K4- S. fibuligera VIT-MN04 toxin, K5B. custersianus VIT-MN05 toxin

The purified killer toxin was found to be a monomer and showed strong killer activity against foodborne pathogens. Similar results were reported by Buzdar $\boldsymbol{e}$ al., (2011).

\section{CONCLUSION}

This study suggests that killer toxin produced from probiotic yeast can be a promising approach to maintain a good health of host by enhancing its antagonistic activity against some of the foodborne pathogens. The killer toxin was active and stable under acidic and $\mathrm{NaCl}$ conditions which may improve the quality of food during the fermentation process. The results could suggest that killer toxin producer probiotic yeasts $K$. lactis VIT-MN02 and L. starkeyi VITMN03 may have potential applications in food and pharmaceutical industries.

Acknowledgements: The authors are thankful to Vellore Institute of Technology (VIT), Vellore, Tamil Nadu, India for providing all necessary facilities in the laboratory.

\section{REFERENCES}

Amin, T., Thakur, M., \& Jain, S. C. (2013). Microencapsulation-the future of probiotic cultures. J microbiol Biotechnol Food Sci, 3, 35-43.

Bajaj, B.K, Sharma, S. (2010). Construction of killer yeast Saccharomyces cerevisiae HAU-1 and its fermentation performance. Brazilian Journal of Microbiology, $41 \quad$ (2), 477-485. http://dx.doi.org/10.1590/S1517 83822010000200030

Bajaj, B.K., Raina, S., Singh, S. (2012). Killer toxin from a novel killer yeast Pichia kudriavzevii RY55 with idiosyncratic antibacterial activity. Journal of Basic Microbiology, 53 (8), 645-656. https://doi.org/10.1002/jobm.201200187 Belgacem, Z.B., Rehaiem, A., Bernárdez, P.F., Manai, M., Castro, L.P. (2012) Interactive effects of $\mathrm{pH}$ and temperature on the bacteriocin stability by response $\begin{array}{lllll}\text { surface } & \text { analysis. } & \text { Microbiology, } & 81 & \text { (2), }\end{array}$ https://doi.org/10.1134/S002626171201002X

Buzdar, M. A., Chi, Z., Wang, Q., Hua, M. X., Chi, Z.M. (2011). Production, purification and characterization of novel killer toxin from Kluyveromyces siamensis against pathogenic yeast in crab. Applied Microbiology and Biotechnology, 91 (6), 1571-1579. https://doi.org/10.1007/s00253-011-3220-8

Chi, Z.M., Liu, G., Zhao, S., Li, J., Peng, Y. (2010). Marine yeasts as biocontrol agents and producers of bio-products. Applied Microbiology and Biotechnology, 86 (5), 1227-1241. https://doi.org/10.1007/s00253-010-2483-9

Francois, Z. N., Perin, M. F. G., Marie, K. P. (2013). Antimicrobial activity of probiotic strain Lactobacillus plantarum isolated from" sha'a" and assessment of its viability in local honey. J Microbiol Biotechnol Food Sci, 3, 226-231.

Golubev, W.I. (2013). A Kluyveromyces lactis mycocin active at neutral pH Microbiology, 82 (3), 290-294. https://doi.org/10.1134/S0026261713030065

Hernández, A., Martín, A., Córdoba, M.G, Benito, M.J, Aranda, E., PérezNevado, F. (2008). Determination of killer activity in yeasts isolated from the elaboration of seasoned green table olives. International Journal of Food
Microbiology, 121
(2)
$178-188$

https://doi.org/10.1016/j.ijfoodmicro.2007.11.044

Kaur, R., Tiwari, S.K. (2016). Isolation, identification and characterization of Pediococcus pentosaceus LB44 and Weissella confusa LM85 for the presence of bacteriocin-like inhibitory substances (BLIS). Microbiology, 85 (5), 540-547. https://doi.org/10.1134/S00262617160500

Laemmli, U.K. (1970). Cleavage of structural proteins during assembly of head of bacteriophage T4. Nature, 227, 680-685. https://doi.org/10.1038/227680a0 
Lopes, C.A, Sangorrin, M.P. (2010). Optimization of killer assays for yeast selection protocols. Revista Argentina de Microbiología, 42 (4), 298-306. http://doi.org/10.1590/S0325-75412010000400011

Meneghin, M.C., Reis, V.R, Ceccato-Antonini, S.R. (2010). Inhibition of bacteria contaminating alcoholic fermentations by killer yeasts. Brazilian Archives of Biology and Technology, 53 (5), 1043-1050. http://dx.doi.org/10.1590/S1516-89132010000500006

Parveen, R.M., Begum, J.A. (2010). Production and effect of killer toxin by Saccharomyces cerevisiae on sensitive yeast and fungal pathogens. International Journal of Pharmaceutical Sciences Review and Research, 3 (1), 127-129.

Pfeiffer, P., Radler, F. (1928). Comparison of killer toxin of several yeasts and the purification of a toxin of type K 2. Archives of Microbiology, 137 (4), 357 361. https://doi.org/10.1007/BF00410734

Ragavan, M.L., Das, N. (2017) Molecular identification of probiotic yeast strains and their characterization. Asian Journal of Pharmaceutical and Clinical Research, 10 (10), 339-343. https://doi.org/10.22159/ajpcr.2017.v10i10.20052

Santos, A, San Mauro, M., Bravo, E., Marquina, D. (2009). PMKT2, a new kille toxin from Pichia mambranifaciens, and its promising biotechnological properties for control of the spoilage yeast Brettanomyces bruxellensis. Microbiology, 155 (2), 624-634. https://doi.org/10.1099/mic.0.023663-0

Younis, G., Award, A., Dawod, R.E., Yousef, N.E. (2017). Antimicrobial activity of yeasts against some pathogenic bacteria. Veterinary World, 10, 979-983. https://doi.org/10.14202/vetworld 